\title{
Deterioration in Qualitative and Quantitative Parameters of Sugarcane due to Yellow Leaf Disease
}

\author{
Sujeet Pratap Singh*, S.K. Vishwakarma and Atul Singh
}

Plant Pathology Division, Sugarcane Research Institute, UP Council of Sugarcane Research, Shahjahanpur - 242 001, UP, India

*Corresponding author

\section{A B S T R A C T}

Keywords

Yellow leaf disease (YLD), Sugarcane, Macro and micro nutrient, Qualitative and quantitative traits

Article Info

Accepted:

17 November 2018

Available Online:

10 December 2018
Yellow leaf disease (YLD) is becoming a serious concern in sugarcane worldwide. The crop production and quality are going down due to the infection of this disease in sugarcane. An experiment was conducted to find out the effect of YLD on yield and quality of two early (Co 0238, CoS 03251) and two mid late (CoS 97261, Co 05011) sugarcane cultivars at SRI, Shahjahanpur during the year 2015-16. The results revealed remarkable reduction in qualitative and quantitative traits after infection of YLD. The average losses in quality and yield were found 2.40 per cent and 11.11 per cent, respectively. The content of macro nutrients $(\mathrm{N}, \mathrm{P}, \mathrm{K})$ and micro nutrients $(\mathrm{Zn}, \mathrm{Fe}, \mathrm{Cu}$, $\mathrm{Mn})$ were also reduced in infected plants as compared to healthy plants. Maximum incidence $(30 \%)$ of YLD was observed on variety Co 05011 at Shahjahanpur location. It is suggested that commercial cultivation of sugarcane should be done using healthy seed material and breeding programme be initiative for developing YLD resistant clone of sugarcane. These approaches would undoubtedly check the losses occurring due to YLD and increase cane productivity as well as quality of sugarcane.

\section{Introduction}

Sugarcane yellow leaf disease (YLD) is one of the most prevalent diseases of sugarcane worldwide. This disease is caused by sugarcane yellow leaf phytoplasma (SCYLP), a specific $16 \mathrm{SrXII}$ group of phytoplasma associated with this disease and also caused by Sugarcane yellow leaf virus (SCYLV; Luteovirus) in India. Sugarcane yellow leaf virus (SCYLV) belonging to the genus Polerovirus, family Luteoviridae, causes yellow leaf disease in sugarcane. YLD was first reported in Hawaii during 1988 (Schenck, 1990) and in India during 1999 (Rao et al., 2000). Thereafter, it was found in other sugarcane growing regions of the world. Sugarcane yellow leaf syndrome (SYLS) associated with sugarcane yellows leaf phytoplasma (SCYP) was first reported in India (Gaur et al., 2008). Most recently mix infection of SCYLV and Candidatus phytoplasma was reported from Egypt (ElSayed et al., 2016). In India, SCYLV has 
been reported from U.P., Haryana, Maharashtra and Tamil Nadu (Rao et al., 2000).

YLD is becoming a serious concern affecting quality and productivity significantly in most sugarcane-growing regions. Yield losses with the incidence of YLD have been reported up to $38 \%$ in India (Iqbal et al., 2015) and up to $50 \%$ in Brazil (Lockhart et al., 2000). YLD is now playing a major role in yield losses of sugarcane in several countries. Quality attributes are also significantly influenced by this disease (Grisham et al., 2001). Nutrition in the sugarcane plant can be drastically altered by many pathogens viz., fungus, bacteria, virus and phytoplasma (Smith et al., 2000). The changes in of nutrient content level may occur in sugarcane crop due to biotic and abiotic stress resulting in nutrient deficiency or excessive nutrients (Matsuoka and Meneghin, 1999). Present work illustrates a detail study on survey, symptomology, quality traits, yield, micro and macro nutrients status in commercial sugarcane cultivars affected in Uttar Pradesh (UP).

\section{Materials and Methods}

An extensive survey of YLD was carried out during 2015-16 in various sugarcane mill zones of Uttar Pradesh. YLD was observed in AICRP trials, planted at the farm of Sugarcane Research Institute (SRI), Shahjahanpur. Four sub-tropical sugarcane cultivars including two early (Co 0238 and CoS 03251) and two mid maturing (CoS 97261 and Co 05011) were grown at SRI farm. Impact of the disease on quality traits such as brix per cent (BR) and sucrose per cent in juice (SUC) were analysed using standard procedures described by Meade and Chen (1977). Purity coefficient (PUR) and commercial cane sugar percent (CCS \%) was calculated using following formulae:

$\mathrm{PUR}=(\mathrm{SUC} / \mathrm{BR}) \mathrm{X} 100$
$\mathrm{CCS} \%=[\mathrm{SUC}-(\mathrm{BR}-\mathrm{SUC}) 0.4] \mathrm{X} 0.73$

The aforesaid four varieties with YLD symptom were selected for qualitative and quantitative analysis. Leaf sample from infected and healthy plant of above mentioned varieties were collected for analysis of macro $(\mathrm{N}, \mathrm{P}, \mathrm{K})$ and micro ( $\mathrm{Zn}, \mathrm{Fe}, \mathrm{Cu}, \mathrm{Mn}$ ) nutrient content. Macro nutrients such as Nitrogen $(\mathrm{N})$, Phosphorus $(\mathrm{P})$ and Potash $(\mathrm{K})$ were analysed by CHNS (Carbon, hydrogen, nitrogen, and sulphur) analyser, Vanadate-molybdate colour method and flame photometer, respectively. Micro nutrients content ( $\mathrm{Zn}, \mathrm{Fe}, \mathrm{Cu}, \mathrm{Mn}$ ) were analysed by using Atomic Absorption Spectrophotometer (AAS) as per standard procedure.

\section{Results and Discussion}

\section{Survey and surveillance}

Usually the characteristic symptoms of YLD appear during 6-8 months crop age and last till maturity phase of the crop. The symptoms of YLD appeared as a distinct yellowing of leaves spreading laterally from the midrib into the lamina, and leaves begin to die from the tip. The incidence of YLD varied from 1 - 30 per cent on several popular cultivars at SRI, Shahjahanpur followed by 10 - 20 per cent observed at Sultanpur, Faizabad and Balrampur districts. Variety Co 05011 was severely affected with the highest severity of 30 per cent at Shahjahanpur. Wider range of spreading of YLD in other part of UP was also observed with the incidence of 2-20\% and 10$15 \%$ at Seorahi and Gorakhpur, respectively in eastern Uttar Pradesh (Table 1). The results of disease survey indicated that YLD is spreading rapidly in cane grower fields in most part of Uttar Pradesh and most of the varieties are affected with YLD with incidence of $1-30 \%$. The results also indicate an increasing threat of YLD by affecting more cultivars in Uttar Pradesh (Table 1 and Fig. 1). 
The cultivars having high incidence of YLD infection showed disease susceptibility. Many cultivars are being utilized as proven parents in hybridization program. Hence, there is ardent need to remove this disease though management programme and to generate YLD free progenies for further utilization in breeding programmes (Comstock and Miller, 2003).

\section{Analysis of qualitative and quantitative traits}

Two early (Co 0238, CoS 03251) and two mid maturing (CoS 97261, Co 05011) were compared with healthy and YLD infected plants. YLD infected plant showed significant reduction in quality and yield parameters as compare to corresponding healthy plants. Commercial cane sugar per cent (CCS \%) varied from 11.64 to 12.56 per cent in healthy crop while 11.27 to 12.35 in infected plants. Reduction in CCS per cent ranged from 1.67 $\%$ (Co 0238) to $3.26 \%$ (Co 05011) in infected plants due to YLD infestation. The reduction in cane weight ranged from 5.88
(CoSe 03251$)$ to $22.22 \%(\mathrm{CoS} 97261)$ in the affected plant in a particular cultivar. Thus, the average losses in quality and yield were estimated to be 2.40 per cent and 11.11 per cent, respectively. A comparative perusal of the results exhibited remarkable reduction in quality and yield due to YLD infection in major sugarcane varieties (Table 2).

Reduction in quality and yield parameters in YLD infected plants in the present study, possibly occurred due to alteration in metabolic activities of plants caused by the infection of phytoplasma or RNA virus. This finding is in agreement with the earlier findings in which yield losses of 15 to $20 \%$ have been reported due to YLD in Louisiana (Grisham et al., 2002) and also losses in sugar yield (Grisham et al., 2001). Earlier, up to 50 $\%$ yield losses in Brazil, up to $14 \%$ losses in sugar yield, $11 \%$ losses in stalk weight and sugar yield have also been reported due to YLD infestation. Qualitative and quantitative traits were also reduced by $11 \%$ and $28 \%$, respectively in Reunion (ElSaye et al., 2015).

Table.1 Incidence of YLD on various sugarcane varieties at different locations of UP

\begin{tabular}{|c|l|c|l|}
\hline $\begin{array}{c}\text { Sl. } \\
\text { No. }\end{array}$ & \multicolumn{1}{|c|}{ Commercial cultivars } & $\begin{array}{c}\text { Incidence } \\
\%\end{array}$ & \multicolumn{1}{|c|}{ Locations } \\
\hline $\mathbf{1}$ & $\begin{array}{l}\text { Co 05011, CoS 08279, CoS 08272, CoSe 01434, Co 0118, } \\
\text { Co 0238, UP 05125, CoS 8436 }\end{array}$ & $1-30 \%$ & $\begin{array}{l}\text { SRI Farm, } \\
\text { Shahjahanpur }\end{array}$ \\
\hline $\mathbf{2}$ & $\begin{array}{l}\text { CoS 767, CoH 10262, CoS 8436, Co 10221, CoPb 10181, } \\
\text { Co 10035, CoS 10231, CoPant 84211, CoLk 11201, CoLk } \\
11203, \text { Co 0238, CoH 11262, CoS 11232, Co 11027, CoLk }\end{array}$ & $10-20 \%$ & $\begin{array}{l}\text { AICRP Trials, } \\
\text { SRI Farm }\end{array}$ \\
\hline $\mathbf{3}$ & $\begin{array}{l}\text { 11206, CoH 11263, CoLk 11204, } \\
\text { CoSe 01434, CoS 08272, Co 0118, Co 0238, CoS 08279 }\end{array}$ & $10-20 \%$ & $\begin{array}{l}\text { Sultanpur, } \\
\text { Rauzagaon, } \\
\text { Balrampur }\end{array}$ \\
\hline $\mathbf{4}$ & Co 0238, Co 0118, CoS 08272, CoS 08279, CoSe 08452 & $2-20$ & Seorahi \\
\hline $\mathbf{5}$ & Co 0238, Co 0118, CoS 08272, CoSe 08452 & $10-15$ & Gorakhpur \\
\hline
\end{tabular}


Table.2 Qualitative and quantitative traits in leaf of healthy and YLD infected plants of sugarcane cultivars

\begin{tabular}{|c|c|c|c|c|c|c|}
\hline \multirow[t]{2}{*}{ Cultivars } & \multirow[t]{2}{*}{ Variable } & \multicolumn{4}{|c|}{ Qualitative traits } & \multirow{2}{*}{$\begin{array}{c}\text { Quantitative trait } \\
\text { Cane weight } \\
\text { (Kg) }\end{array}$} \\
\hline & & $\begin{array}{c}\text { Brix } \\
\%\end{array}$ & $\begin{array}{c}\text { Sucrose \% in } \\
\text { juice }\end{array}$ & $\begin{array}{c}\text { Purity } \\
\%\end{array}$ & $\begin{array}{c}\text { CCS } \\
\%\end{array}$ & \\
\hline \multirow[t]{3}{*}{ Co 0238} & Healthy & 20.6 & 18.4 & 89 & 12.56 & 12.56 \\
\hline & Infected & 20 & 17.86 & 88.41 & 12.35 & 11.68 \\
\hline & $\begin{array}{c}\text { Reduction } \\
\%\end{array}$ & 2.91 & 2.93 & 0.66 & 1.67 & 7.00 \\
\hline \multirow{3}{*}{$\begin{array}{l}\text { CoS } \\
03251\end{array}$} & Healthy & 20 & 17.6 & 88 & 12.14 & 6.80 \\
\hline & Infected & 19.05 & 17.1 & 87.71 & 11.78 & 6.40 \\
\hline & $\begin{array}{c}\text { Reduction } \\
\%\end{array}$ & 4.75 & 2.84 & 0.33 & 2.96 & 5.88 \\
\hline \multirow{3}{*}{$\begin{array}{l}\mathrm{CoS} \\
97261\end{array}$} & Healthy & 19.2 & 16.88 & 87.94 & 11.64 & 9.0 \\
\hline & Infected & 19.76 & 16.84 & 85.22 & 11.44 & 7.0 \\
\hline & $\begin{array}{c}\text { Reduction } \\
\%\end{array}$ & - & 0.24 & 3.03 & 1.72 & 22.0 \\
\hline \multirow[t]{3}{*}{ Co 05011} & Healthy & 19.26 & 16.9 & 87.72 & 11.65 & 9.6 \\
\hline & Infected & 19.49 & 16.3 & 85.19 & 11.27 & 8.68 \\
\hline & $\begin{array}{c}\text { Reduction } \\
\%\end{array}$ & - & 3.55 & 2.88 & 3.26 & 9.58 \\
\hline
\end{tabular}

Table.3 Macro and micro nutrient contents in healthy and YLD infected plants of sugarcane cultivars

\begin{tabular}{|c|c|c|c|c|c|c|c|c|}
\hline \multirow[t]{2}{*}{.Cultivars } & \multirow[t]{2}{*}{ Variable } & \multicolumn{3}{|c|}{ Macro nutrients (\%) } & \multicolumn{4}{|c|}{ Micro nutrients (ppm) } \\
\hline & & $\mathbf{N}$ & $\mathbf{P}$ & $\mathbf{K}$ & $\mathbf{Z n}$ & $\mathrm{Fe}$ & $\mathrm{Cu}$ & Mn \\
\hline \multirow[t]{3}{*}{ Co 0238} & Healthy & 1.59 & 0.24 & 1.67 & 38.8 & 508 & 1.67 & 1.67 \\
\hline & Infected & 0.76 & 0.14 & 1.24 & 20.8 & 453 & 1.24 & 1.24 \\
\hline & Reduction \% & 52.20 & 41.67 & 25.75 & 46.39 & 10.83 & 35.0 & 31.94 \\
\hline \multirow[t]{3}{*}{ CoS 03251} & Healthy & 1.38 & 0.17 & 2.43 & 30 & 503 & 2.43 & 2.43 \\
\hline & Infected & 0.97 & 0.1 & 2.05 & 27 & 378 & 2.05 & 2.05 \\
\hline & Reduction \% & 29.71 & 41.41 & 5.64 & 10.0 & 24.85 & 55.63 & 27.91 \\
\hline \multirow[t]{3}{*}{$\operatorname{CoS} 97261$} & Healthy & 1.53 & 0.15 & 1.53 & 53 & 336 & 1.53 & 1.53 \\
\hline & Infected & 1.11 & 0.11 & 1.43 & 28 & 378 & 1.43 & 1.43 \\
\hline & Reduction \% & 27.45 & 26.67 & 6.54 & 47.17 & 17.86 & 29.63 & 41.89 \\
\hline \multirow[t]{3}{*}{ Co 05011} & Healthy & 2.03 & 0.18 & 1.3 & 58 & 676 & 1.30 & 1.3 \\
\hline & Infected & 1.45 & 0.12 & 1.12 & 37 & 503 & 1.12 & 1.12 \\
\hline & Reduction \% & 29.56 & 33.33 & 13.85 & 36.21 & 25.69 & 32.86 & 24.42 \\
\hline
\end{tabular}


Fig.1 Symptom of yellow leaf disease in variety Co 0238

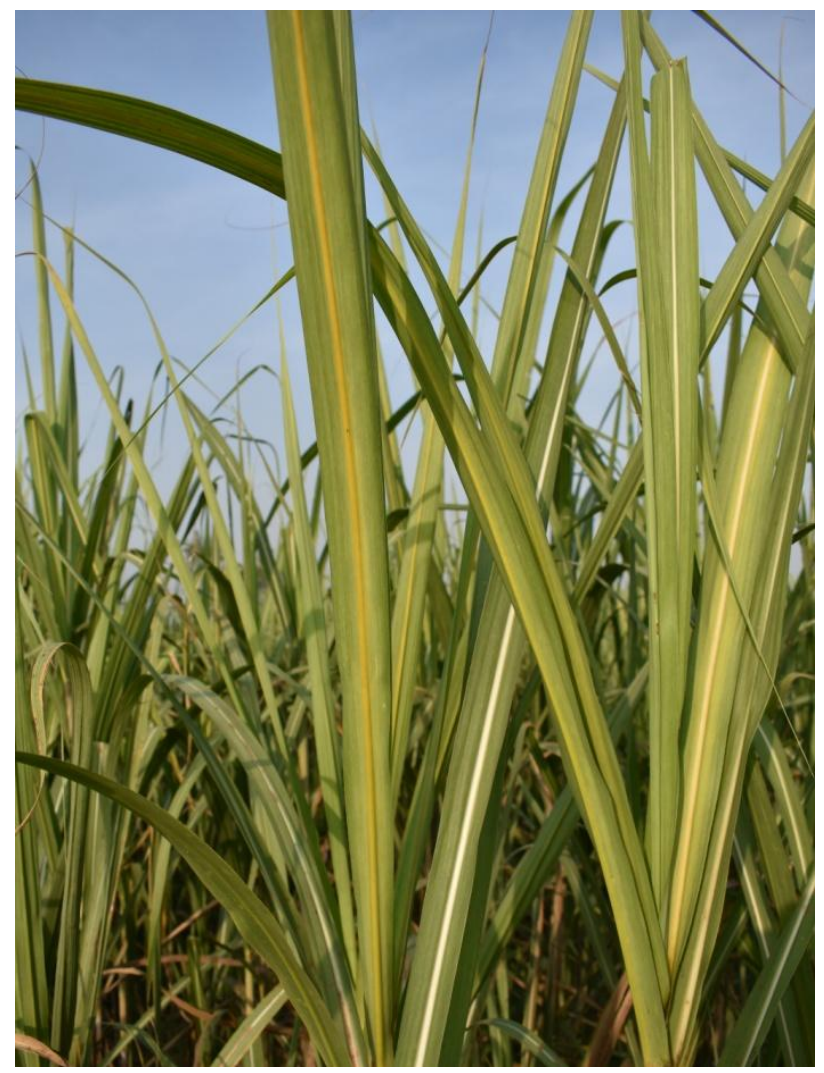

Viswanathan et al., (2014) reported a reduction in plant growth by $39-43 \%$ and juice yield by $30-34 \%$ at harvest in India. Reduction in cane yield due to the infection of YLD in combination with phytoplasma, has been reported by earlier workers (Aljanabi $e t$ al., 2001; Iqbal et al., 2015).

\section{Macro and micro nutrients analysis}

The effect of YLD on macro nutrient (N, P, $\mathrm{K})$ and micro nutrients $(\mathrm{Zn}, \mathrm{Fe}, \mathrm{Cu}, \mathrm{Mn}$, ) were studied. Results revealed that the reduction in leaf macro nutrient $\mathrm{N}$ content ranged from $27.45 \%(\mathrm{CoS} 97261)$ to $52.20 \%$ (Co 0238). Leaf $\mathrm{P}$ and $\mathrm{K}$ contents were decreased from 26.67 to 41.67 and 5.64 to $25.75 \%$ in the cultivars, respectively. Maximum reduction in leaf micro nutrient $\mathrm{Zn}$ was observed to be $47.17 \%(\mathrm{CoS} 97261)$ and Fe contents was recorded 25.69\% (Co 05011).
Maximum reduction in leaf $\mathrm{Cu}$ and $\mathrm{Mn}$ contents was observed in CoSe 03251(55.63\%) and CoS 97261 (41.89\%), respectively (Table 3 ).

The overall results revealed that the qualitative and quantitative traits reduced due to incidence of YLD in most of the commercial cultivars. Reduction in the macro and micro nutrients status in infected plant as compare to respective healthy plants was also found remarkable. YLD and phytoplasma diseases are transmitted by several vectors with broad host range due to climate change (ElSayed et al., 2015). There is a need to explore the detailed genetic diversity of SCYLV and phytoplasma also, to gather more information on its vector, its variable host with actual causal agent so that effective management strategies could be formulated. Screening and evolution of YLD resistant 
cultivars is also necessary. The effective management of YLD by removing virus and phytoplasma from cane stalk through chemotherapy is a tough task. Hot water treatment of seed materials is more successful method to remove phytoplasma. Use of fresh virus-free cane plants generated through meristem tip culture from virus infected seed of commercial sugarcane may be successful approach for proliferation of that cultivar under seed programme. YLD free plant could also be screened through molecular tools using marker assisted selection. Subsequently, commercial cultivation of sugarcane cultivars should be initiated using healthy seed material for sustainability of sugarcane cultivars.

\section{Acknowledgement}

Authors are thankful to Dr Aneg Singh, Sr. Scientific Officer and Dr Priyanka Singh, Scientific Officer, for their support in the analysis of samples for nutrient and quality, respectively.

\section{References}

Aljanabi, S.M., Y. Parmessur, Y. Moutia, S. Saumtally and Dookun A. 2001. Further evidence of the association of a phytoplasma and a virus with yellow leaf syndrome in sugarcane. Plant Pathol., 50:628-636.

Comstock, J.C. and Miller J. D. 2003. Incidence and spread of sugarcane yellow leaf virus in sugarcane clones in the cp-cultivar development program at canal point. Journal American Society of Sugarcane Technologists, Vol. 23.

ElSayed, A.I., E. Komor, M. Boulila, R. Viswanathan and Odero D.C. 2015. Biology and management of sugarcane yellow leaf virus: An historical overview. Arch Virol., DOI 10.1007/s00705-015-2618-5.
ElSayed, A.I., Z. Soufi, K.M. Wahdan and Komor E. 2016. Detection and characterization of phytoplasma and sugarcane yellow leaf virus associated with leaf yellowing of sugarcane. Journal of Phytopathology, 164 (4): 217-225.

Gaur, R.K., R. Raizada and Rao G.P. 2008. Sugarcane yellow leaf phytoplasma associated for the first time with sugarcane yellow leaf syndrome in India. Plant Pathol., 57:772.

Grisham, M.P., Y.B. Pan, B.L. Legendre, M.A. Godshall and Eggleston G. 2001. Effect of sugarcane yellow leaf syndrome on sugarcane yield and juice quality. Proc. Intern. Soc. Sugar Cane Technologists, 24: 434-438.

Iqbal, A., A.K. Tiwari, Kavita and Rao G.P. 2015. Detection of mixed infection of phytoplasmas and yellow leaf virus in commercial sugarcane cultivars and their impact on yield and quality parameters. Phytopathogenic Mollicutes, 5 (1-Suppl.): S95- S96.

Lockhart, B.E.L. and Cronje C.P.R. 2000. Yellow leaf syndrome. In: Rott P, Bailey RA, Comstock JC, Croft BJ, Saumtally AS (eds) A guide to sugarcane diseases. CIRAD-ISSCT, Montpellier, pp 291-295.

Matsuoka, S. and Meneghin S.P. 1999. Yellow leaf syndrome and alleged pathogens: Causal, not causal relationship. Proc Int Soc Sugar Cane Technol Congress, 23:382-389.

Meade, G.P. and Chen J.C.P. 1977. "Cane Sugar Hand Book (10th) Wiley Inter Science," John Wiley and Sons, New York, 1977, p. 947.

Rao, G.P., R.K. Gaur, M. Singh, A.K. Srivastava, K.S. Virk, N. Singh, R. Viswanathan, A.S. Patil and Jain R.K. 2017. Occurrence of sugarcane yellow leaf virus in India. Sugar Tech, 2 (7): 37-38. 
Schenck, S. 1990. Yellow leaf syndrome a new sugarcane disease. Annual Report, Hawaiian Sugar Planters Association, pp 38-39.

Smith, G.R., Z. Borg, B.E.L. Lockhart, K.S. Braithwaite and Gibbs M.J. 2000. Sugarcane yellow leaf virus: a novel member of the Luteoviridae that probably arose by interspecies recombination. J. Gen. Virol.,
81:1865-1869. Viswanathan, R., C. Chinnaraja, P. Malathi, R. Gomathi, P. Rakkiyappan, D. Neelamathi and Ravichandran V. 2014. Impact of sugarcane yellow leaf virus (ScYLV) infection on physiological efficiency and growth parameters of sugarcane under tropical climatic conditions in India. Acta Physiol. Plant, 36:1805-1822

\section{How to cite this article:}

Sujeet Pratap Singh, S.K. Vishwakarma and Atul Singh. 2018. Deterioration in Qualitative and Quantitative Parameters of Sugarcane due to Yellow Leaf Disease. Int.J.Curr.Microbiol.App.Sci. 7(12): 2320-2326. doi: https://doi.org/10.20546/ijcmas.2018.712.263 